ESJ Humanities

\title{
Shareholders' Lawsuit in Georgian Legislation and Case Law
}

\author{
Khatuna Jinoria, PhD Candidate
}

Grigol Robakidze University, Georgia

\section{Doi:10.19044/esj.2021.v17n20p1}

Submitted: 02 March 2021

Accepted: 24 June 2021

Published: 30 June 2021
Copyright 2021 Author(s)

Under Creative Commons BY-NC-ND

4.0 OPEN ACCESS

Cite As:

Jinoria K. (2021). Shareholders' Lawsuit in Georgian Legislation and Case Law. European Scientific Journal, ESJ, 17(20), 1. https://doi.org/10.19044/esj.2021.v17n20p1

\begin{abstract}
Obtaining shares in a joint stock company grants the owner important rights and imposes several obligations on them. In the list of shareholders' rights, one of the most important subjects is the right to sue the shareholder's lawsuit. The right to bring in front of courts certain aspects of company-related activities is the legal mechanism of protecting the shareholders other rights. Shareholders' lawsuit plays an important role in the protection of minority shareholders. Shareholders' lawsuit also includes two types of legal actions: direct lawsuit and derivative lawsuit. Georgian case law is not very advanced in this area. When shareholders bring matters in front of courts, the number of precedents adhered to is rare. As for the derivative lawsuit, the relative novelty of this legal institution in Georgian legislation causes the lack of deeper understanding. Georgian doctrine does not provide thorough analysis of legal nature and divergence of shareholders' lawsuits when it comes to case law. As mentioned above, it is quite scarce.
\end{abstract}

Keywords: Shareholders' rights, Shareholder's lawsuit, Direct lawsuit, derivative lawsuit

\section{Introduction}

The extent to which a member or shareholder should be able to influence the organization as a whole is one of the most general conceptual issues in the development of company law provisions (Vutt, 2008, p.76). The nature and protection of shareholders' rights are closely related to the question of the extent to which shareholders, as the providers of certain resources to the company, should have the right to check the use of these resources. When a 
majority of shareholders observe that a member of a directing body of the company has infringed or is infringing on his or her obligations, the shareholder can usually respond to the situation, at a minimum, by replacing the member of the directing body and thus ensuring the possibility of claiming damages on behalf of the company. A minority shareholder's possibilities to influence the directing bodies are minimal. Yet, one of the important tools, available for minority shareholders, is the shareholder's lawsuit. The right to bring in front of courts certain aspects of company-related activities is the legal mechanism for the protection of the shareholders' rights. Shareholders' lawsuit plays an important role in the protection of minority shareholders.

Shareholders' lawsuit also includes two types of legal actions: direct lawsuit and derivative lawsuit. Georgian case law is not very advanced in this area. Derivative lawsuit is a relatively new legal institution in Georgian legislation. As a result, the understanding of its legal nature is limited. On some occasions, Georgian courts did not differentiate derivative lawsuit from direct lawsuits.

Thus, it is vital to develop further Georgian legal doctrine and establish clear parameters of distinction between direct and derivative lawsuits. The distinction between these two types of action bares not only theoretical but very tangible practical value. Derivative lawsuit differs from direct lawsuit not only in the result of proceedings but in preliminary procedures as well as in the application of evidentiary standards and allocation of burden of proof. In addition, the remedies benefit different parties. "A successful derivative claim typically enriches the corporate treasury, while a successful direct claim typically puts money directly in the hands of the shareholder claimant. Moreover, derivative defendants can shelter behind several powerful bulwarks, including special litigation committees and the business judgment rule that are unavailable to direct defendants." (Kleinberger, 1996, p.1)

In some cases, the distinction between lawsuits is clear even at first sight. However, in more complex issues, the breach of shareholder's certain rights might become a basis for both types of lawsuits. "Corporate matter" approach suggests that in any case, when the direct benefactor of the lawsuit is the company, it should be considered as derivative lawsuit. Nonetheless, as shown below, there are cases when the end result is not primarily beneficial for the plaintiff shareholder, but the lawsuit is based on direct violation of the rights that each shareholder enjoys in the company. For this reason, the claim is still considered as direct. In other words, the subject is trickier than it seems at first sight.

This paper analyzes the doctrinal contexts that may serve as a legal platform for resolving the difficulties that Georgian courts have in this area. The paper is focused on basic analysis of each type of lawsuits. In the interest of protection of minority shareholders and proper development of case law, 
thorough research of legal incidents is required. For proper analysis, it is important to examine and take into consideration international experience, legislation, and legal precedents of other countries representing continental or common law systems. After general research of each type of lawsuit, the paper provides a basis for their distinction and main criteria for the courts to properly identify and address, in a compatible manner, the shareholder's claim brought in front of them.

The research is based on general scientific methodology. Abstractive logical methodology is broadly used which includes analysis and synthesis, induction and deduction. Comparative legal methodology of research was also applied. Relevant research activity was organized in several layers in order to guarantee accurateness and completeness of the paper. At first, theoretical aspects of both types of lawsuits were studied by researching relevant Georgian and foreign doctrine. After setting theoretical scope in place, relevant Georgian legislation was studied and compared to generally accepted principles. Also, problematic areas where identified. Georgian case law on the subject was also collected and studied to establish its comparison with relevant doctrine and European practice. The results of the study were generalized and logical conclusions were drawn that are represented in the paper.

The paper consists of two main chapters dedicated to each type of lawsuits. The results of the research are summarized in the conclusion and are provided with necessary recommendations for further development of the topic.

\section{Direct Lawsuit}

In learning to distinguish between direct and derivative lawsuits, it is useful to first understand each claim in its pure form. A shareholder asserts a direct claim to vindicate some right that is personal to the shareholder. The shareholder suffers directly from the harm, rather than as a consequence of damage to the corporation (Kleinberger, 1996, p.7).

Ownership of shares or stocks in a corporation gives rise to certain legal rights. All legal systems establish main rights and responsibilities of shareholders. Traditionally, the rights are divided into proprietary rights and rights related with corporate governance. More recent legal doctrine offers other criteria for classification such as individual and quota-based rights, rights related with general meeting, rights independent from meeting, etc. (Burduli Irakli, 2013, p.40). Regardless of the classification, some basic rights recognized in some form by any legal system include:

- Membership rights;

- Right to dividends;

- Right to attend general meeting and vote;

- Right to demand early general meeting; 
- Access to information;

- Opportunity to inspect corporate books and records;

- The right to sue for wrongful acts.

Denial or breach of any of these rights provides the basis for direct lawsuit. Shareholders enjoy these rights themselves and the limitation or breach of any of them causes damage to specific shareholder. As a result, the shareholder has direct claim, i.e., a suit by the shareholder in his own right to redress an injury sustained directly by him for which he is entitled to personal relief. For example, if the shareholder is denied the right to inspect the corporate books and records in good faith and at a reasonable time, he may sue the corporation to compel its directors to permit him to examine the books.

Entrepreneurs Law of Georgia (EL) provides shareholders with the right to lodge a complaint against decisions of general meeting, and such claim is also direct. It is worth mentioning that in Germany, the claim demanding nullification of the decision of general meeting is separated and is measured autonomously (nichtigkeitsklage - nulity suit). EL does not provide such distinction, but even if it were singled out, nullity suit in its legal nature is direct claim.

Denial or impediment of voting rights as well as breach of rules of calling general meeting and reaching the decisions at the meeting, provided by EL or charter of the corporation, is basis for direct lawsuit as well. Most shareholder lawsuits in Georgian case law are of this type. One way or another they are related with the validity of the decisions of general meetings or procedural violations. More so, the shareholders do not always draw direct benefits from these actions. The fact that lawsuit relates with the specific right enjoyed by the shareholder usually classifies this action as direct.

Another example of direct lawsuit worth mentioning separately is provided by the article 3.8 of EL: If a dominant partner of an enterprise has intentionally abused his/her dominant position to the detriment of the company, he/she shall pay the corresponding compensation to the rest of the partners. A partner or a group of partners acting together, holding a controlling vote at the Meeting of Partners, shall be considered a dominant partner.

The specific nature of this particular claim is that the company suffers damage through abuse of power by dominant partner. However, direct claim belongs to shareholders. It is debated in literature whether this particular lawsuit is direct or derivative, since shareholders do not sustain direct damage. Nevertheless, the fact that minority shareholders are suing on their own behalf 'instead' of the company is the characteristic that puts this claim in line with other direct lawsuits. Another decisive factor is the allocation of burden of proof. There is no special rule in this case, and it is quite similar to any tort case which states that plaintiff minority shareholders are obliged to prove damage and respondent dominant shareholder must disclaim the abuse of 
power or negate the damage or guilt. In the case of derivative lawsuits, specific rules apply which will be discussed in the next chapter.

The group of shareholder's managerial rights includes the following rights that are connected with management of the company, decision-making, and controlling managerial bodies such as the right to attend general meeting, voting rights, the right to demand early general meeting, the right to obtain information, preemptive right of acquisition of stocks, and the opportunity to inspect corporate books and records. Denial or violation of any of these rights may be brought in front of court in form of direct lawsuit.

Without providing shareholders with information, their participation in general meeting will not be efficient. Shareholders ought to be regularly updated with information concerning important tendencies taking place in the company. On one hand, the access to information is an important tool to protect minority shareholders. On the other hand, the access to information contains several risks such as abuse of one's rights. The shareholder is entitled to address a court in case of the refusal of sharing the information. The court must be very careful while delivering justice and expel the risk of abuse of rights before putting obligation on directors of the company to share requested information.

Main property rights of shareholders are preemptive right of acquisition of stocks and entitlement to dividends. If the shareholder is denied the option of preliminary acquisition of stocks, it is also the basis for direct lawsuit.

When it comes to dividends, more complex issues must be addressed. Georgian case law is quite advanced in this area. The Supreme Court of Georgia established common practice few years ago. According to clarifications of the Supreme Court, the share in capital owned by the partner of the company is the right to demand economical and legal benefits, and the right of dividends is the most important. The Court of Cassation distinguished the general right to receive dividends and the right to demand declared dividends at the end of economic year, i.e., the right to demand dividends. The difference between both rights is that general right of dividends originates as soon as a person acquires stocks of the company, i.e., becomes the partner or shareholder, whilst the right to demand dividends is granted to a shareholder after general meeting makes a decision on marshalling of income between shareholders. In other words, the right to compel payment of declared dividends is a right dependent on the decision of general meeting (partners meeting). General right of dividends is linked with stocks and cannot be transferred separately from shares to another person. The right to demand dividends can be applied even after transition of stocks by former shareholder if it is stated that the decision of general meeting to declare dividends was made and given when shareholder did not receive his lot. This kind of misuse 
of power by majority shareholders happened quite often in Georgia during the past 20 years. Several cases were discussed by Georgian courts where a single shareholder or the group of majority shareholders had held general meetings without inviting minority shareholders, and they had made decisions to declare dividends among themselves. The minority shareholders or non-minority shareholder that the other partners tried to force into sell-out of stocks were never informed about the decision and were simply deceived that there was no income to share as dividends. As soon as those abused shareholders found out about the breach of their rights and brought actions against the companies and majority, the court granted them their portion of dividends.

However, the situation is completely different in cases where general meeting has not made the decision on marshalling income. Georgian courts established that courts are not empowered to force corporate management to declare dividends. No matter how unreasonable the decision of nondistribution of dividends is, only corporate bodies are entitled to make this kind of decision and it could be quite harmful to force the company to use the income for dividends. It is presumed that managerial bodies of the company act in the best interest of the company. To make the decision on how to marshal income is a great risk, which is not justified even by the purpose of protection of minority shareholders.

On this matter, it must also be noted that a suit to compel declaration of dividends is very well recognized and established long time ago in other legal systems. For example, in the USA, the appropriate case law was established in early 1950's (Compare Knapp v. Bankers Sec. Corp., 230 F.2d 717 (3d Cir. 1956) with Gordon v. Elliman, 306 N.Y. 456, 119 N.E.2d 331 (1954)). By denying the right to compel declaration of dividends, Georgian courts leave minority shareholders unprotected. To rely solely on a presumption that managerial bodies of the company are acting in the best interest of the company and they have a better understanding of how the income of the company should be disposed and thus declare decisions about dividends as 'internal matter' of the company is not the best approach. This gives the majority the opportunity to abuse their power. In addition, the action to compel declaration of dividends is not always successful since the courts elsewhere, reluctant to interfere with directors' business judgment, have placed a heavy burden of proof upon the plaintiff. As a result, completely denying such possibility is a huge omission in the process of protection of the minority shareholders' interests.

In some cases, direct lawsuit is not limited by the partnership of the company. If the shareholder sustained direct damage, he or she is entitled to demand compensation even after selling shares or stocks. Certainly, the former shareholder is not authorized to argue denial to access of information or 
violations of voting rights after exiting the company, unless he or she proves direct and continued damaged that is still being sustained.

\section{Derivative Lawsuit}

'A stock certificate represents the shareholder's pro rata interest in the net assets of the corporation, and any injury to the corporation is immediately reflected by a diminution in that interest. Nevertheless, the corporation and its shareholders are legally separate and distinct. The corporation is a person and its ownership is a nonconductor that makes it impossible to attribute an interest in its property to its members. Regard for the corporate personality demands that suits to redress corporate injuries which secondarily harm all shareholders alike be brought only by the corporation' (Editors, 1962, p.1148). From this premise comes the conclusion that a shareholder might sue when he or she sustains direct damage and if the interests of the company are violated, the company should claim satisfaction. Derivative lawsuit is an exception to this general principle.

In corporate law, the derivative action mechanism allows minority shareholders and, in certain jurisdictions, single directors or even creditors to file and litigate, on behalf of the corporation, a lawsuit against an insider or a third party whose action has allegedly injured the corporation (Rotem, 2013 p.46). Normally, the decision to take action on the company's behalf lies with the directors, since they generally have the responsibility of managing the company. Hence, in these cases, it is necessary that the shareholders are given the right to commence action on the company's behalf. This is because some or all of the board are responsible for the wrong that has been committed.

The main specification of derivative lawsuit is that the shareholder brings claim in place of the company against third party. The term itself indicates that claim is "derived" from another right. Derivative lawsuit was born and developed in common law system. Scholars and judges often say that the United States imported the shareholder derivative action from England. Nonetheless, this statement is disputed (for more details see Scarlet, 2013). The purpose of this paper is not to track and research the origins of derivative lawsuit, but it is noted that the first elements of derivative actions can be tracked to $19^{\text {th }}$ century in the UK. At first, such claims where not accepted by courts. It had been established that the company and its partners (shareholders) were separate entities and each should argue in their own interest (known as Foss v. Harbottle rule). This principle was later expanded in MacDougall v Gardiner which also states that if the alleged wrong is ratifiable by a majority of the company's shareholders, the minority may not sue. In one of the earliest cases of Carlen v. Drury, the possibility of a partner to bring suit instead of the company was dismissed. However, in the following decade, the action on 
behalf of the company was gradually allowed (Boyle, 2002, p.7-10; Ramsay $\&$ Saunders, 2006, p.3-4).

A shareholder may be precluded from bringing a direct action for damages to his ownership interest was first established in Smith v. Hurd in the USA. Thus, when a corporation is injured through the negligence of its directors, a cause of action exists only in favor of the corporation, even though the shareholders are also injured (Editors, 1962, p.1148).

Despite the hard start, it is a commonly accepted principle today that the shareholder, in some cases, is entitled to litigate 'in place of the company' when the damaged party is the company and not the shareholders.

Georgia was, however, slow in accepting this principle. Originally, EL did not address Derivative lawsuit at all. The possibility for the shareholder of a joint stock company to bring lawsuit instead of the company was provided in 1999. As for limited liability companies, necessary legal amendments were made only in 2016.

Article 53.5 of EL states that if a joint stock company does not assert its claim against any third party, a shareholder may instead, and to the benefit of the company, lodge a suit on his/her behalf for the fulfilment of that claim. Such shareholder shall be deemed a proper claimant if the company does not file an action against the third party within 90 days after receiving a written request to that effect or fails to prove that such an action prejudices the interests of the company. If the court satisfies the claim of the shareholder, the company shall be obliged to indemnify the shareholder for any reasonable outof-court expenses of the action, including attorney's fees. However, the company shall be released from paying such expenses if it proves that satisfying the action is detrimental to the company. If the shareholder is deemed an improper claimant, or the claim is not satisfied, the shareholder shall be liable for any costs and expenses reasonably incurred by the company in the action. Considering the property status of a shareholder, the court may postpone the shareholder's date for payment of court expenses.

Same rule applies to limited liability companies and article 46.5 of EL states that if a limited liability company does not assert its claim against any third party, a partner may instead, and to the benefit of the company, lodge a suit on his/her/its behalf for the fulfilment of that claim. Such partner shall be deemed a proper claimant if the company does not file an action against the third party within 90 days after receiving a written request to that effect or fails to prove that such an action prejudices the interests of the company. If the court satisfies the claim of the partner, the company shall be obliged to indemnify the partner for any reasonable out-of-court expenses of the action, including attorney's fees. However, the company shall be released from paying such expenses if it proves that satisfying the action is detrimental to the company. If the partner is deemed an improper claimant, or the claim is not 
satisfied, the partner shall be liable for any costs and expenses reasonably incurred by the company in the action. Considering the property status of a partner, the court may postpone the partner's date for payment of court expenses.

The mandatory prerequisite of derivative lawsuit states that a company must have a claim against any third party that it is not asserting. The second characteristic of the derivative lawsuit is that a shareholder (partner) lodges a suit instead to the benefit of the company. Thus, if a suit is characterized as derivative, any amount recovered belongs to the corporation not to the plaintiff. When a suit is characterized as direct, the amount recovered goes straight to the shareholder.

The Supreme Court of Georgia stated more than once that the shareholder filing derivative lawsuit is the representative of the company (decisions of the Supreme Court of Georgia N as- 727-695-2016, as- 687-6582016 , etc.). The description is not precise but it grasps the main nature of derivative lawsuit of shareholder's acting in their interests and instead of the company.

Characterization of an action as direct or derivative comes with legal incidents, which implement these policy considerations and highlight the competing interests involved. A wrongful act depletes or devalues corporate assets or undercuts the corporate business. The shareholder suffers harm indirectly as a consequence of damage done to the corporation. The wrongful conduct relates to the shareholder through the medium of the corporation, i.e., by reducing the value of the shareholder's stock. In essence, a derivative plaintiff seeks to derive standing from the injury to the corporation and to represent the corporation's interests in the derivative lawsuit (Kleinberger, 1996, p.14-15).

If the derivative lawsuit is successful, the result is beneficial to all shareholders, since the raise of actives of the company raises the value of the stocks.

According to EL, another mandatory precondition for the derivative lawsuit states that before addressing the court, the shareholder must place demand, in written form, from the company to assert its claim against the third party. However, if the company refuses to file an action, the shareholder gains the claim instead of the company.

Georgian courts had to deal with the problem of distinction between shareholders lawsuits and underlying procedural differences in 2009. The circumstances of the cases were as follows: Shareholder A owned in joint stock company "TC" $50.1 \%$ of shares, while JSC "TC" owned shares in limited liability company "DC". This is in alliance with another shareholder $\mathrm{B}$, who owned $2 \%$ of shares. A forced the decision to transfer the property of JSC "TC" to himself, including the shares in ltd "DC". A group of 
shareholders, who owned $16 \%$ of shares, were against the decision and they filed a complaint against A and JSC "TC." They demanded nullification of the decision of general meeting, arguing that A had no right to vote, since the decision involved transfer of goods to him and this was conflict of interests.

The Court of First Instance and Court of Appeal stated that it was a derivative lawsuit. Court of Appeal stated that the decision involved transfer of property of shares in a limited liability company. If the decision of the general meeting were nullified, the result would have been return of the shares to JSC. If the decision was against the interests of JSC, proper plaintiff was the company not the shareholders. Therefore, the Court of First Instance and Court of Appeal found the claim inadmissible since the group of shareholders had not filed written request in accordance with article 53.5 of EL.

However, the Supreme Court of Georgia stated that article 53.5 of EL did not apply in this case. The Court of Cassation stated that the group of shareholders was disputing violation of voting rights and they were not lodging complaint against the third party (decision of the Supreme Court of Georgia N as-1194-1455-09).

As earlier mentioned above, derivative lawsuit is filed in cases when the company was injured and the shareholder is protecting corporate interests instead of the company. Thus, direct lawsuit is a shareholder's private matter and derivative lawsuit raises corporate issues. Nevertheless, this case is a clear indication that between the definitive poles of the direct action to reify a shareholder's right of inspection and the derivative suit to recover lost corporate assets lies a blurred area where, because both the shareholder and the corporation have been significantly injured, it becomes difficult to distinguish between a "personal right" and a "corporate cause of action" (Compare Editors, 1962, p.1147-1149). The decision of the court resulted to the restoration of the property of JSC and, subsequently, the lawsuit involved corporate cause of action. Plaintiffs voting rights were violated and they also suffered direct damage. As a result, the lawsuit was classified as direct.

Another case of derivative claim in article 56.4 of EL states that the directors must perform the tasks incumbent on them faithfully and diligently. If a director fails to fulfil his/her duties, he/she shall be obliged to reimburse the company for damages inflicted. The directors shall be jointly and severally liable with all their assets. If the fact of causing damage is established, the directors must evidence that they have managed the business in accordance with article 9 (6) of this Law. The company may not waive a claim for damages. The creditors of the company may exercise the right of claim unless they have been compensated by the company for their claims.

Same rule is provided in article 9.6 of EL which states that the persons referred to in the first paragraph of this paper and the members of the Supervisory Board shall conduct the company's business in good faith. In 
particular, they shall take care as an ordinary person of sound mind in a similar capacity and under similar circumstances, acting in the faith that their action is in the best interests of the company. If they fail to fulfil that obligation, they shall be jointly and severally liable for damages incurred by the company with all their assets, directly and proximately. The company's waiver of the right of recourse or any similar compromise by the company shall be void if the refund is necessary to satisfy creditors' claims. If the refund is necessary, the liability of the heads of the company shall not cease on the grounds that they acted based on the direction of the partners.

In a more recent case, the Supreme Court of Georgia stated that the shareholder (partner) had right to control the actions of the company. In this light, derivative lawsuit serves the interests of corporate governance. The Court of Cassation declared that derivative lawsuit can be lodged in the case of breach of fiduciary duties by managerial bodies of the company. Derivative lawsuit is a mechanism of control of the directors of the company. Derivative lawsuit also guarantees that damage caused by the wrongful actions of the director will be restored to the company (Decision of the Supreme Court of Georgia N as-559-2019).

The decisions mentioned above indicate that Georgian courts are finally grasping the complicated nature of shareholders lawsuits, but the case law is not numerous.

EL provides one more primary example of derivative lawsuit. Article 9.5 states that by violating conflict of interest rules, if the persons referred to in the first paragraph of this paper inflict any damage upon the company, they shall surrender the right to remuneration from the company and shall reimburse the damages. A claim for reimbursement of damages may be exercised by a shareholder or a group of shareholders owning 5 percent or more of the stock in a joint stock company, and by every partner in all other companies.

It is the only case in Georgian legislation when derivative lawsuit is limited by the amount (percentage) of shares. In any other case, a single shareholder, regardless of percentage of shares, is entitled to file the derivative lawsuit.

As earlier mentioned, direct lawsuit is not limited by the membership of the company and in some cases, it can be brought by a former shareholder. Nonetheless, derivative lawsuit is the action enjoyed only by the current shareholders of the company. The limitation is compatible with the nature of the lawsuit, since derivative lawsuit is filed instead of the company to protect the "common good". Unless one is part of the corporation, there is no interest for such litigation.

The defendant of direct lawsuit is the corporation, majority or dominant shareholder, while the proper defendant of derivative lawsuit is the 
third party against whom the company has claim. However, the company should also be part of the litigation of a mandatory party.

Another specific issue related with derivative lawsuit is the allocation of burden of proof. On one hand, the direct lawsuits burden of proof is shared equally by the parties. In case of derivative claim, burden of proof is reversed. It lies on the plaintiff shareholder while the managerial bodies of the company are protected by business judgement rule.

Heavy burden of proof is one of the reasons why shareholders refrain from bringing cases in front of courts and Georgian case law is not very rich.

In another case, brought in front of courts, $49 \%$ shareholders demanded compensation for damages, i.e., 10144 USD in favor of the company from the director. Plaintiff claimed that the director was not acting in the best interest of the company.

While Tbilisi City Court stated the possibility of filing derivative lawsuit for the breach of fiduciary duties, the lawsuit was dismissed since the plaintiff was unable to pierce business judgement rule. The Court of Appeal of Tbilisi and the Supreme Court of Georgia supported the decision of first instance (judgment of the Supreme Court of Georgia N as-766-766-2018).

To be fair, derivative actions are not quite that popular elsewhere. A study prepared for European Commission showed that Derivative actions are rare in Europe. A particularly important issue is cost rules. A rule that requires the shareholders to advance the costs of the proceedings and imposes the litigation risk on them aggravates the collective action problem (GernerBeurle, Paech, \& Shuster, 2013, p.17).

Same problem applies to Georgia as well since the shareholder, who lost the litigation, is liable to reimburse all costs to the company, which is the risk shareholders are not willing to take. On the other hand, court fees and legal expenses protect companies from drowning into unmerited lawsuits.

Further analysis shows that lack of popularity of derivative lawsuits are due to four main problems: a) the damage is not made directly to the shareholder and the shareholder is not interested to act instead of the company; b) positive outcome is highly questionable. It is quite difficult to prove that bringing charges against third party is in the best interest of the company while managerial bodies claim otherwise. Burden of proof lies on the plaintiff shareholder; c) derivative actions have bad impact on companies' reputation and make investors more reluctant to deal with those companies; d) great expenses of civil litigation (compare Boyle, 2002, p.9).

The derivative action must provide a balance between giving an effective remedy to shareholders while at the same time allowing the directors of a company reasonable freedom from shareholder interference (Ramsay \& Saunders, 2006, p.4). In other words, effective management of the company is impossible. 
In the case of breach of fiduciary duties, shareholders may also bring direct lawsuit if they argue damage sustained directly by themselves.

Contrary to most European countries, in Georgia, the holder of even one share is entitled to lodge derivative lawsuit in most cases. This is a better approach for protection of minority shareholders (compare Gerner-Beurle, Paech, \& Shuster, 2013, p.192-199).

It is important to mention that even if the number of cases is limited, recent case law on derivative lawsuits is developing in the right direction in Georgia.

\section{Conclusion}

To sum up, few important characteristics of direct and derivative lawsuits can be listed:

1. Direct lawsuit addresses damage that the shareholder has sustained. It aims to rectify the breach or violations that have direct impact on shareholders' interests. Derivative lawsuit addresses corporate matter, as well as the claim that the company has and is not using. The shareholder acts in place of the company and the result is beneficiary for the company. This is the basic distinction between them.

2. The derivative lawsuit is brought up in corporate matters in cases when the result is beneficiary to the company. However, in some cases, if both the company and shareholder have sustained damage, direct lawsuit can also be filed.

3. Under EL, the mandatory prerequisite for derivative lawsuit is that the shareholder must place demand, in written form, from the company to use the claim against the third party. However, if the company is not asserting claim, the shareholder may address the court.

4. Direct lawsuit is not limited by membership of the company. In some cases, the former shareholder may take an action if the damage was sustained while being a shareholder. Derivative lawsuit is the remedy enjoyed only by current shareholders.

5. Burden of proof lies on plaintiff in the case of derivative lawsuits. Managerial bodies of the company are protected by 'business judgement rule'. On direct lawsuits, the allocation of burden of proof is typical and both parties share the burden equally.

6. Direct lawsuit is not limited by amount (percentage) of shares. The only case when derivative lawsuit is limited by percentage of shares in Georgia is in article 9.5 of EL.

7. Breach of fiduciary duties as well as the right to dividends can be a basis for both derivative and direct lawsuits. 
Consequently, the characteristics listed above are not merely theoretical. They have important practical value. The court could use them in the process of dealing with shareholders litigations to distinguish derivative lawsuits from direct lawsuit and properly address the matter at hand. It is worthy to note that even though Georgian courts experienced difficulty in proper placement of shareholders actions, more recent case law shows that they are grasping tricky nature of shareholders claims. With the aid of legal theory, practice must be developed in the right direction.

\section{References:}

1. Bainbridge, S.M. (2002). Corporation Law and Economics, New York (Foundation Press).

2. Boyle, A.J. (2002). Minority Shareholder's Remedies, Cambridge, Cambridge Studies in Corporate Law.

3. Burduli Irakli (2013). Essentials of JSC Law, vol. 2, Tbilisi.

4. Case of Knapp v. Bankers Sec. Corp., 230 F.2d 717 (3d Cir. 1956).

5. Case of Gordon v. Elliman, 306 N.Y. 456, 119 N.E.2d 331 (1954).

6. Decision of the Supreme Court of Georgia N as-559-2019.

7. Decision of the Supreme Court of Georgia N as-1194-1455-09.

8. Decision of the Supreme Court of Georgia N as- 727-695-2016.

9. Editors, Distinguishing Between Direct and Derivative Shareholder Suits, University of Pennsylvania Law Review, Vol 110:1137; https://scholarship.law.upenn.edu/penn_law_review/vol110/iss8/5.

10. Entrepreneurs Law of Georgia, Register of The Parliament of Georgia, 21-22, www.matsne.gov.ge, 01.2021.

11. Gerner-Beurle, C., Paech, P., \& Shuster, E.P. (2013). Directors' Duties and Liability in the EU, Study Prepared for the European Commission, http://eprints.lse.ac.uk/50438/

12. Gibbs-Kneller, D. \& Gindis, D. (2019). De jure convergence, de facto divergence: A comparison of factual implementation of shareholder derivative suit enforcement in the United States and the United Kingdom, European Business Law Review, https://www.academia.edu/42877408/De_jure_convergence_de_facto _divergence_A_comparison_of_factual_implementation_of_sharehol der_derivative_suit_enforcement_in_the_United_States_and_the_Uni ted_Kingdom

13. Hollington, R. (2004). Shareholder's Rights, Fourth Edition, London, (Sweet\&Maxwell).

14. Judgment of the Supreme Court of Georgia N as-766-766-2018.

15. Judgment of the Supreme Court of Georgia N as- 687-658-2016 
16. Kleinberger, D. S. (1996). Direct vs. Derivative, or What's a Lawsuit Between Friends in an 'Incorporated Partnership'? Mitchel/Hamline school of law, Faculty Scholarship Paper 223, http://open.mitchellhamline.edu/facsch/223.

17. Ramsay, I.M. \& Saunders, B.B. (2006). Litigation by Shareholders and Directors: An Empirical Study of the Statutory Derivative Action, SSRN Electronic Journal 6, https://papers.ssrn.com/sol3/papers.cfm?abstract_id=914465

18. Riley, C. (2014). Derivative claims and ratification: Time to ditch some baggage. Legal Studies, 34(4), 582-608, https://www.cambridge.org/core/journals/legalstudies/article/abs/derivative-claims-and-ratification-time-to-ditchsome-baggage/001605AC00F93A91DE81BF5EEFDEDB67

19. Rotem, Y. (2013). The Law Applicable to a Derivative Action on Behalf of a Foreign Corporation - Corporate Law in Conflict, Cornell International Law Journal, 321 https://scholarship.law.cornell.edu/cilj/vol46/iss2/3/

20. Scarlet, A. M. (2013). Scarlett, Ann M., Shareholder Derivative Litigation's Historical and Normative Foundations, Buffalo Law Review, Vol. 61, https://ssrn.com/abstract=2358209

21. Vutt, M. (2008). Shareholder's Derivative Claim - Does Estonian Company Law Require Modernisation?, Juridica International XV, https://www.juridicainternational.eu/article_full.php?uri=2008_XV_7 6_shareholders-derivative-claim-does-estonian-company-lawrequire-modernisation 